\title{
Remodeling the American Suburb, Obesity, Parklets and Social Media
}

\author{
By Michael O’Brien *
}

Unlike most European countries, the United States is suffering through an epidemic of obesity, type II diabetes, and hypertension among its adults and children. The Centers for Disease Control (CDC) estimates over 35\% of adults in the U.S. have obesity, and $17 \%$ of children suffer from the condition, which the American Heart Association has classed as a disease. Simultaneously, retail markets have undergone a significant centralization, the small neighborhood green grocers and fish markets are gone in most all neighborhoods, replaced with big box grocery stores selling less and less fresh foods as their supply chains stretch farther and farther across the country and the world. In a study of 13,102 adults, Rundle and Neckerman have found that walkable access to stores selling healthy foods is associated with a lower prevalence of obesity. Many other scientific studies have drawn similar conclusions, the combination of an auto-centric environment, and past generational models of centralized retail are slowly killing many Americans, and are a significant driver of societal health care costs. Americans didn't used to be like this. Even those not associated with an agrarian or heavy industrial lifestyle were not routinely obese. Something changed in postwar planning, and postwar retail thinking and the interaction between these two factors is causing a significant reduction in the quality of life of American citizens. Yet, place an American citizen, in the early stages of the obesity in Paris, or Athens for a month, and their condition slowly begins to reverse. The National Institutes of Health recommend focusing on balancing energy taken in with energy exerted, eating healthier foods, and adopting a healthy lifestyle. But the suburban life-pattern of house to car, car to market, car to work has made the adoption of these recommendations difficult for most Americans. Before the widespread adoption of refrigeration, it was routine to walk to the store to get milk for the day, beer for the evening, fruits and vegetables for the day, and meat and fish for the evening meal. Most Americans lived near enough that they walked, purchased, walked home, and ate fresh food, not canned. It was considered normal for a subdivision plan to include local retail land uses, between the streetcars or bus stop and the residential district so it was convenient to get off the bus, stop for groceries, and walk home. Everyday. This paper will propose a renovation plan for a typical American small suburban town. The plan will include the historical propositions for neighborhood units seen in progressive era subdivisions and new towns and will illustrate prototype scales of retail that use social media to effectively bring healthy foods within an achievable distance of most of the towns residents.

* Professor, Texas A\&M University, USA. 


\title{
Historical Cases of Walkable Suburbs
}

\author{
Introduction: The Neighborhood Unit
}

When the American suburb was first coming to form as the "streetcar suburbs", walking was an accepted fact and an accepted form of transportation. Social reformers like Jacob Riis theorized a school centered community form in the early 1900's, ${ }^{1}$ and Arthur Comey, planner in $1915 .^{2}$ As early as 1923 planners recognized that automobiles were congesting city infrastructure and that they needed to be advocates for walkable communities. ${ }^{3}$ One planner/ sociologist, Clarence Perry made a coherent proposition at the 1923 National Planning Conference in Washington DC. Perry proposed that a citizen should be able to access the goods and services necessary for life within a five-minute walking distance. ${ }^{4}$ Perry called this place where services and goods would be accessible the "Neighborhood Unit" (see Figure 1) and proposed it be anchored by a school for $800-1500$ students and it would be bounded by arterial streets keeping interior streets small scale to reduce the risk of collision between children walking to school and the automobile. ${ }^{5}$

The quarter-mile (5-minute) walk to the center gave Perry approximately 160 acres to develop into single-family detached housing. He argued that commercial and retail functions should happen along the periphery of the neighborhood where they could be serviced by the arterial roads (and serve the adjacent neighborhood) so in effect, each half mile there would be a small commercial center. He further argued for playgrounds adjacent to the school, and parks throughout the development.

Perry did not believe that the government should mandate the neighborhood unit concept. He believed real estate developers had to be convinced that this was an appropriate and profitable land use pattern. To help convince them, he developed prototypes of the neighborhood unit model for Single family detached housing types, ${ }^{6}$ "industrial sections,", low density apartments, ${ }^{8}$ and high-density apartments. ${ }^{9}$ (See Figure 2.)

1. Mel Scott, American city planning since 1890 (Chicago, IL: American Planning Association, 1995), 72.

2. John Nolen, City planning: a series of papers presenting the essential elements of a city plan, 2nd edition (ed.) John Nolen (New York; London: D. Appleton and Company, 1929).

3. N. Byun, Y. Choi and J. Choi, J. "The Neighborhood Unit: Effective or Obsolete?" Journal of Asian Architecture and Building Engineering 13, no.3 (2014): 617-624.

4. B. Harris, "Planning the great metropolis: the 1929 regional plan of New York and its environs," Environment and planning B, Planning and design 25, no.1 (1998): 486-498

5. Ibid, 487.

6. Ibid, 490.

7. Ibid, 492.

8. Ibid, 495.

9. Ibid, 497. 


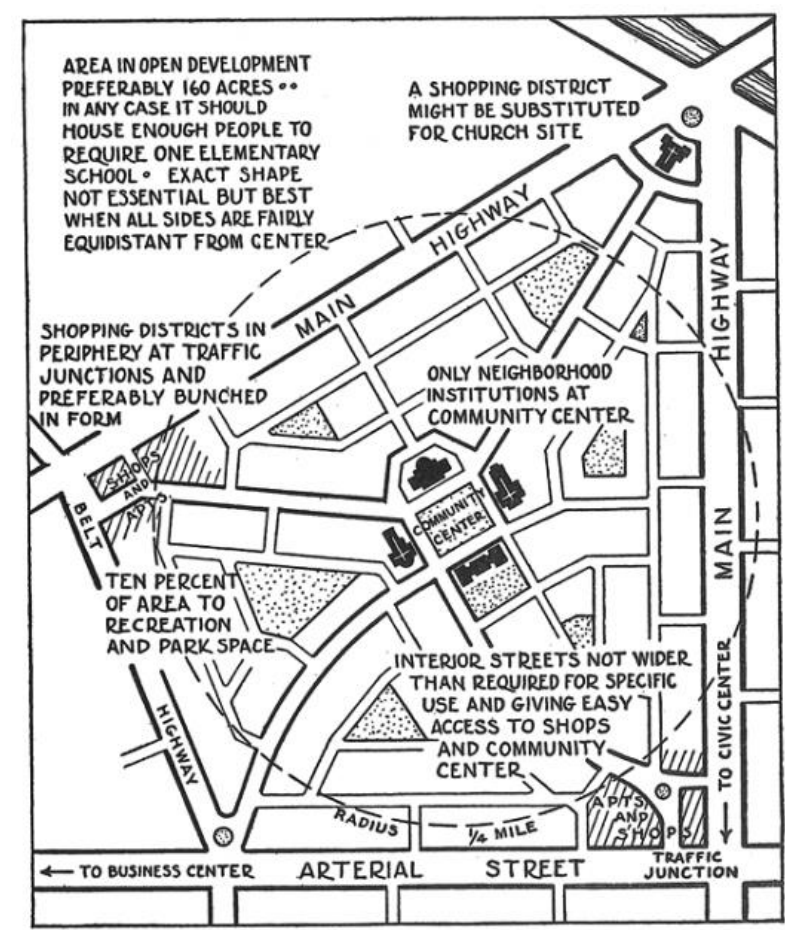

Figure 1. Clarence Perry's Neighborhood Unit Diagram from the "New York Regional Survey, Vol. 71929 from source licensed under Fair Use by Wikipedia
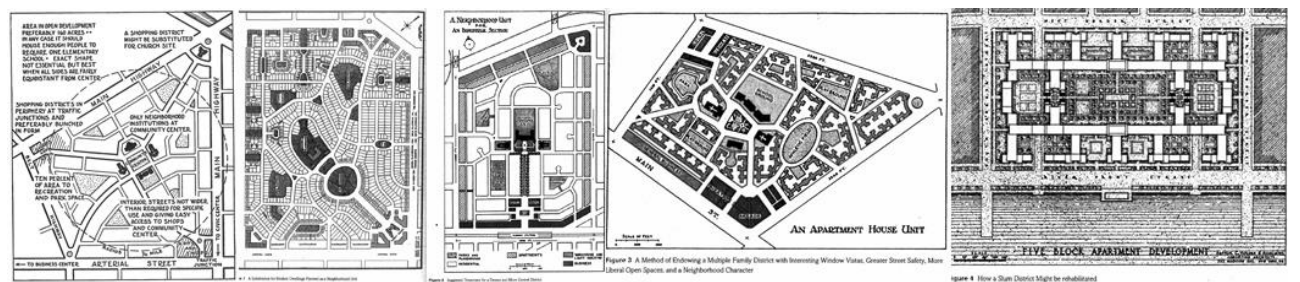

Figure 2. Clarence Perry's Concept, Medium Density, Industrial, High Density and Slum Renovation Neighborhood Unit Schemes

Perry's "Neighborhood units" idea became widely adopted in unique design adaptations by most of the leading landscape architects and planners of the 1920's and 1930's and was included in many of the new towns designs from the interwar years and town designs proposed in the New Deal by government agencies. ${ }^{10}$

10. The Chicago City Club held a design competition to generate ideas for a residential development of a typical quarter-section of land on the Southwest Side of Chicago in 1913. Twenty six of the thirty submitted plans conformed to Perry's ideas of the neighborhood unit. Major new towns and developments designed by the Olmstead Brothers, John Nolen, Alfred Comey, George B. Post, and others similarly conformed to Perry's idea. Forest Hills Gardens, Billerica Garden Suburb, Kingsport Tennessee, Craddock Virginia, Venice Florida, and Mariemont Ohio all incorporated the neighborhood unit concept to one degree or another. The New Deal New-towns of Greenhills Ohio, Greenbrook New Jersey, Greendale Wisconsin, and Greenbelt Maryland incorporated the concept, providing a Federal endorsement of Perry's idea of the suburban neighborhood. 


\section{The Chicago City Club Competition 1916}

The competition for the design of a typical quarter section of land held by the City Club of Chicago in 1913 provides a common ground for observing the practices of the professions competing dominate the emerging field of city planning. The site for this competition is a fictitious quarter section of land located Northwest of the Loop. Competitors were to submit plans to house not more than 1280 families, with associated parks, schools, shops, places of worship and community amenities deemed necessary. Submittals were birdseye view perspectives and a site plans drawn at the scale of 1 " $=80$ '. The Jury was:

- John C. Kennedy, cited as an expert in the emerging field of scientifically designed housing.

- John Arvold, a leading civil engineer

- Jens Jenson, the distinguished landscape architect

- George Maher, Chicago School architect

- A.W. Woltersdorf, architect

- Eward Bouton, Director of the successful development company, Roland Park Company of Baltimore, developer of Roland Park and contributing author to "City Planning," a collection of essays on planning edited by John Nolen in 1929.

There were 41 entries to this competition, 29 were published by the City Club of Chicago. ${ }^{12}$ These 29 entries (including the entry from Frank Lloyd Wright identified as "non-competitive") came from a group made up of seven Landscape Architects, twelve Architects, four Civil Engineers, One City planning spousal team, and five others including a high school student and a medical doctor.

The jury observed that these entries could be placed into five types:

- $\quad$ Grid based schemes

- Heterogeneous schemes

- Systematic repetitions

- Beaux Arts schemes with vistas and boulevards

- And "unified" or "those not in other categories"

The winning scheme was submitted by an architect named Wilhelm Bernhard of Chicago who also listed himself as a city planner. This scheme falls into this last "unified" category. The scheme, shown in Figure 3, Major

11. Nolen, City planning: a series of papers presenting the essential elements of a city plan, 1929, XV.

12. Alfred P. Yeomans, City Residential Land Development, Studies in Planning, Competitive plans for subdividing a typical quarter section of land in the outskirts of Chicago (Chicago, Illinois: University of Chicago press, 1916). 
retail and multifamily construction is grouped along the street car line on the southern edge of the property. Two courtyard spaces are developed as the street passes through, a commercial courtyard (identified as " $\mathrm{B}$ " on the plan) which is circular in form, and spatially defined by the building massing. Slightly larger and falling on the central entry boulevard is what can only be understood as a piazza in the tradition of northern European piazzas as described by Camillio Sitte. ${ }^{13}$ The commercial/high density residential core becomes less dense towards the center of the scheme, developing into a series of landscaped walks and parks. The adjacent city grid is extended into the scheme but is interrupted short of becoming through streets by a looping drive beginning at the northern boundary, looping south almost to the southern boundary. For the most part, this loop drive defines multi family and public spaces within it. The loop drive creates what Unwin has termed "street pictures" - a constantly changing vista, framed by large shade trees. Most of the single-family lots, of varying street frontage fall on the extensions of the city grid into the scheme.

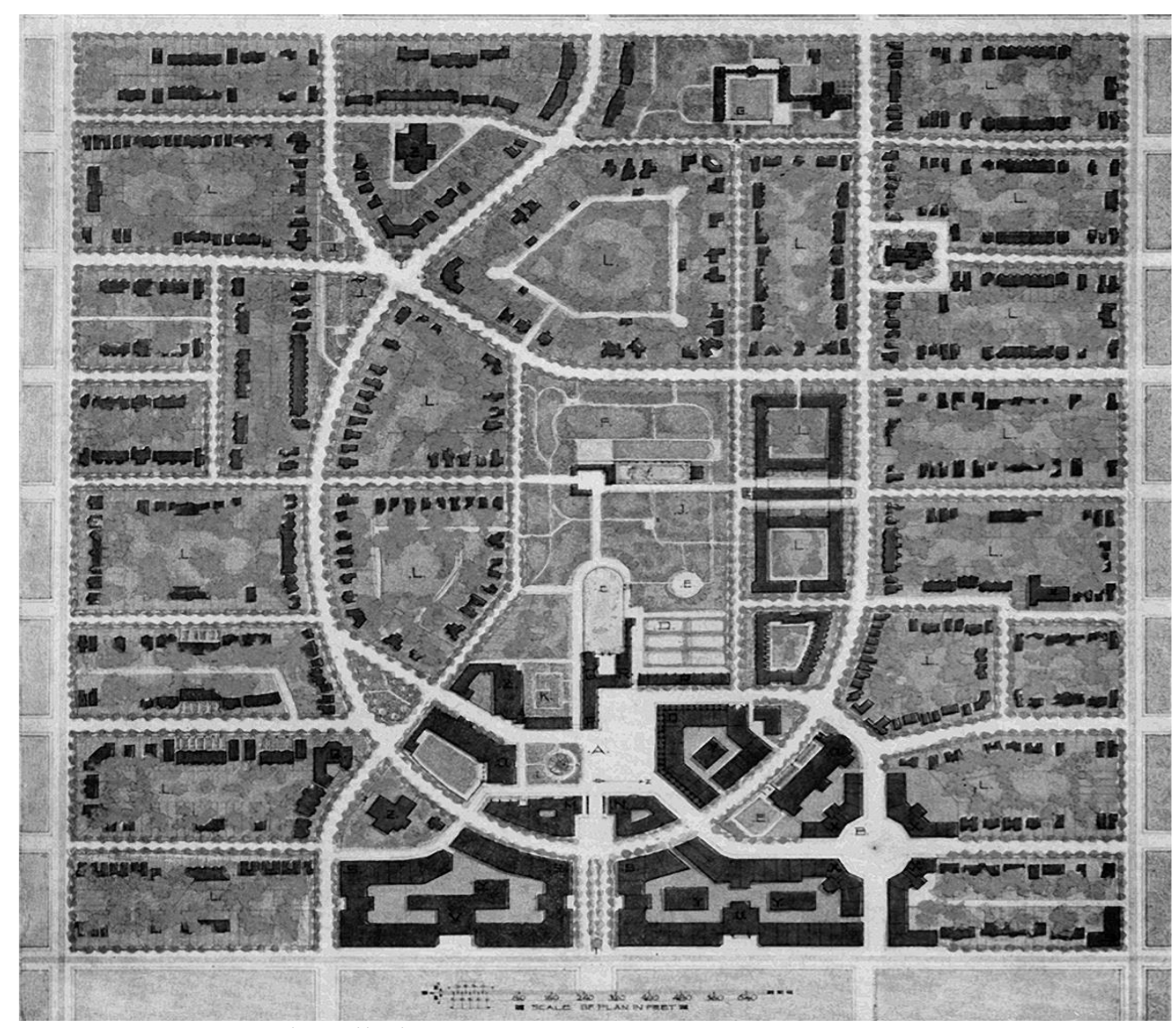

Figure 3. Bernard Wilhelm's Winning Entry to the 1916 Chicago City Club Competition

13. L. Holzner, "Camillo Sitte: The Birth of Modern City Planning with a Translation of the 1889 Austrian Edition of his City Planning Artistic Principles.” Book Review 19, no. 2 (1988): 89 . 
The levels of design in this scheme can be described as:

- Functional overall - being the general locations of major commercial, communal, and residential areas, loop road, central entry from the south, and extension of the city grid into the scheme.

- Neighborhood place making - being the design of lots to facilitate specific urban design responses during the design and construction of buildings.

- $\quad$ Street place making - being the building type selection (single family detached, duplex, row house...) and location to establish a perceptible space at a midblock, corner or axial termination.

Of the twenty two or so blocks shown on this scheme, there are 10 to 12 conditions of street place making, thirteen to fourteen conditions of Neighborhood place making, reinforced by the overall functional planning of the scheme.

Arthur C. Comey, who listed himself as a Landscape Architect, submitted the second place scheme. Comey had been an employee of the Nolen firm sometime after this competition, and was on the faculty at the Harvard School of Planning. ${ }^{14}$ Comey became a leading figure and authored books on transitional zoning. ${ }^{15}$ In one chapter of his 1933 book titled "Transition Zoning", Comey discusses the important role of neighborhood units "A comprehensive city plan must be adopted if a city is to provide adequate neighborhood units where they are needed throughout its area. Unless such a plan is followed, the best suited land will not be acquired in advance of building and the corresponding increase in land values; and this delay will inevitably force cramped facilities, often poorly placed in relation to the district to be served."16

Comey's second prize submission is a hybrid between a grid plan and the "unified" category described by the jurors. The grid is transformed to distort from the orthogonal street pattern (not matching up with the surrounding neighborhood) to meet a diagonal line of travel extending from the Northeast to the Southwest. The diagonal splits and swells to become a large ovoid shape. The project uses single-family dwellings on small lots almost exclusively as the response to density. Attached single family, apartments and some commercial buildings are grouped toward the streetcar lines on the eastern edge of the property. The scheme has minimal public space, which may be a developmental step towards Comey's 1929 position on Neighborhood units and public space. The forecourt and playground to the school being the largest, the rest being made up as seven undeveloped public spaces for allotment gardening or general

14. "John Nolen Office Staff 1908 - 1934" from a file titled "office 1927 - 1937" Accession 2903 John Nolen Collection, Box 16, Rare and Manuscript Collection, Carl A. Kroch Library, Cornell University, Ithaca, New York.

15. Arthur C. Comey, Transition zoning (Cambridge: Harvard University Press, 1933).

16. Arthur C. Comey, "Neighborhood units," in City Planning: A Series of Papers Presenting the Essential Elements of a City Plan (ed.) John Nolen (New York and London: National Municipal League Series, D. Appleton and Company, 1916). 
play. These public spaces have sidewalk connections to the streets, but seem to be strongly associated with the single-family properties surrounding them.

Considering Comey's scheme similarly to Wilhelm's we find the levels of design to be valued differently.

- Functional overall - being the general locations of major commercial, communal, and residential areas, diagonal access, minimal shops, community spaces and the intentional disruption of the existing city grid.

- Neighborhood place making - being the design of lots to facilitate specific urban design responses during the design and construction of buildings. Nine such lots are distributed over the 37 blocks making up the scheme.

- Street place making - being the building type selection (single family detached, duplex, row house...) and location to establish a perceptible space at a midblock, corner or axial termination. Six such conditions, primarily axial terminations, are distributed over the 37 blocks making up this scheme.

The predominance of the single family lot in the overall area, the minimal expectation Comey placed on the buildings of the scheme, and minimal development of public space lead me to conclude Comey placed a high priority on the absolute rights of each homebuyer to build according to their individual needs and to keep their taxation rates low by minimizing public investment in first cost of land and construction and ongoing maintenance, an early affirmation of the contemporary suburban condition.

Critics of this approach argued that it tended to reduce the complexity of the neighborhood, clustering commercial and retail along major arterials instead of scattering them across each street. Jane Jacobs was especially critical in her book "Death and Life of Great American Cities," for the vibrancy of "the life of the street" which, one could argue, is true for the high-density world of a major city, but perhaps is less appropriate for the American Suburb.

\section{John Nolen and the Neighborhood Unit}

As a landscape architect and planner, John Nolen recognized the value of Perry's idea of the neighborhood unit as a formal organizing element for a new-town or subdivision plan. Nolen's designs for Windsor Farms Subdivision in Richmond Virginia, and for the new towns, Mariemont, Ohio; Venice, Florida; Clewiston, Florida; Kingsport, Tennessee; Happy Valley, Tennessee; Bellair, Florida; and Belmont on the Gulf (precursor to Seaside, Florida) (see Figure 4) had plans featuring strong formal centers that were designed to contain shops, government institutions, churches and schools.

17. J. Jacobs, The death and life of great American cities. (New York: Random House, 1961). 

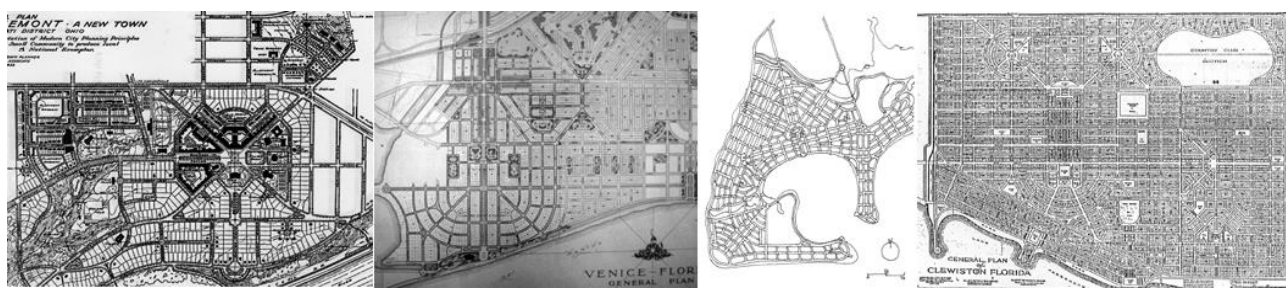

Figure 4. John Nolen New Towns, Mariemont, OH; Venice, Fl; Belmont, Fl; Clewiston, $\mathrm{Fl}$

Few of these were ever realized as Nolen envisioned them. As the landscape architect and planner, Nolen had little control over the "build-out" in most of his new-town and subdivision designs. ${ }^{18}$ Two notable examples where his vision of the neighborhood unit was most closely realized are Mariemont, Ohio, and Windsor Farms in Richmond, Virginia.

Mariemont, Ohio was designed between 1920 and 1925, and remains, perhaps, the best surviving example of John Nolen's vision for the Garden City in America. ${ }^{19}$ Mariemont actually has three "neighborhood units," each with its own characteristics designed according to the functional needs of the new town (see Figure 5). These Neighborhoods overlap, but each has a distinct "center" providing goods or services to residents within a five minute walk.

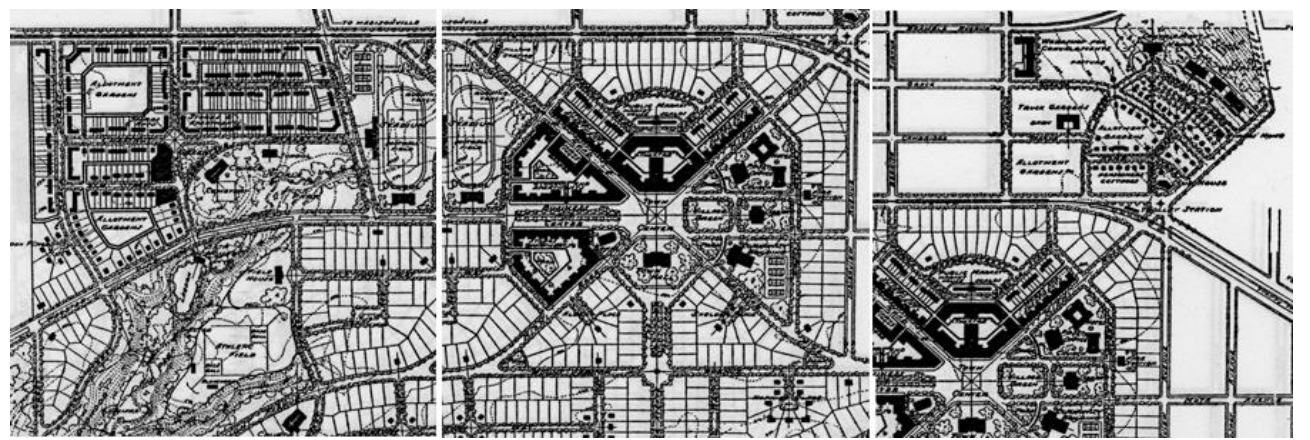

Figure 5. The Three Neighborhood Units in John Nolen's Mariemont

The first neighborhood unit in Mariemont was the town center located in the northeast quadrant of the town at the intersection of Chestnut Street and Oak Street in the Dale Park district. This center was part of the plan constructed first, and housed much of the workforce who would build out the rest of Mariemont. This town center is spatially established by a "face the intersection" condition wherein each of the corner buildings designed by Ripley \& LeBoutillier ${ }^{20}$ features a chamfer making the street intersection into a more prominent urban space. ${ }^{21}$ The buildings themselves follow Arthur Comey's proposal for transitional land uses falling between districts as

18. M. O’Brien, "John Nolen and Raymond Unwin: Garden City Collaborators," Athens Journal of Architecture 1, no.1 (2015): 9-24.

19. Ibid, 13.

20. M. F. Rogers, John Nolen \& Mariemont: building a new town in Ohio. Millard F. Rogers, Jr (Baltimore: Johns Hopkins University Press, 2001), 126.

21. Ibid, 12. 
articulated in his 1933 book, "Transition Zoning."22 Comey proposed that the gateway to residential neighborhoods be developed with multiple function buildings having doctors, pharmacists, barbers and shops at the street level, and apartments above. Nolen's Chestnut at Oak neighborhood unit does just that. This center places retail and office space within a quarter mile radius of high-density townhouses, medium density single-family houses, schools, recreational activities and churches. The fifteen-minute walk to services is part of daily life in northwestern Mariemont (see Figure 6.) Nolen used a factor of four persons per household in his density calculations. This would mean that Figure 6 (below) would be home to 1,540 residents that would form the served population of the service and goods provider in the town center at Oak and Chestnut Streets.

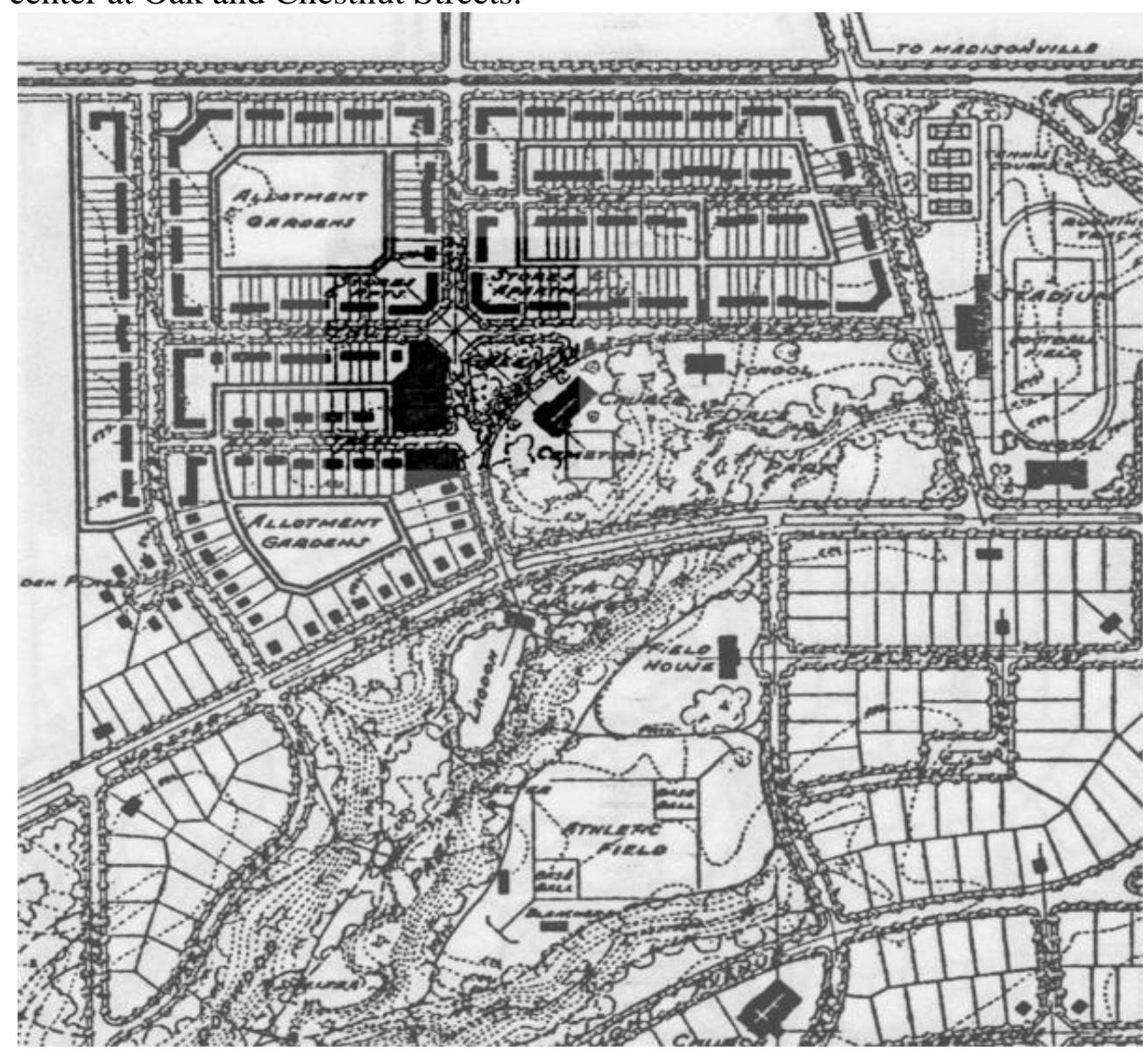

Figure 6. Mariemont Town Center at Oak and Chestnut Streets

The second neighborhood unit in Mariemont is the "Town Center." This center is developed at the crossing the Wooster and Plainville Pikes, two major regional roads that cross the townsite. These roads were slightly rerouted to cross as an elongated " $X$ " shaped intersection. Nolen overlaid a small green at the center of this " $\mathrm{X}$ " and formed the town center around it by

22. Comey, Transition zoning, 1933. 
massing shops and public institutions to visually anchor the center as a highly defined public space. From this primary " $X$ " intersection, Nolen extends a formal boulevard east and west, through the town center. Then develops a north-south boulevard commencing at the "back" of the town hall (which "fronts" on the Town Center space) extending to the axial termination at the concourse and overlook to the Little Miami River on the southern edge of the site. ${ }^{23}$ This neighborhood unit functions as the dominant center of services and goods for all of Mariemont (see Figure 7.) This center is within Perry's 5minute walk of approximately 1,200 persons using Nolen's 4 person per household factor.

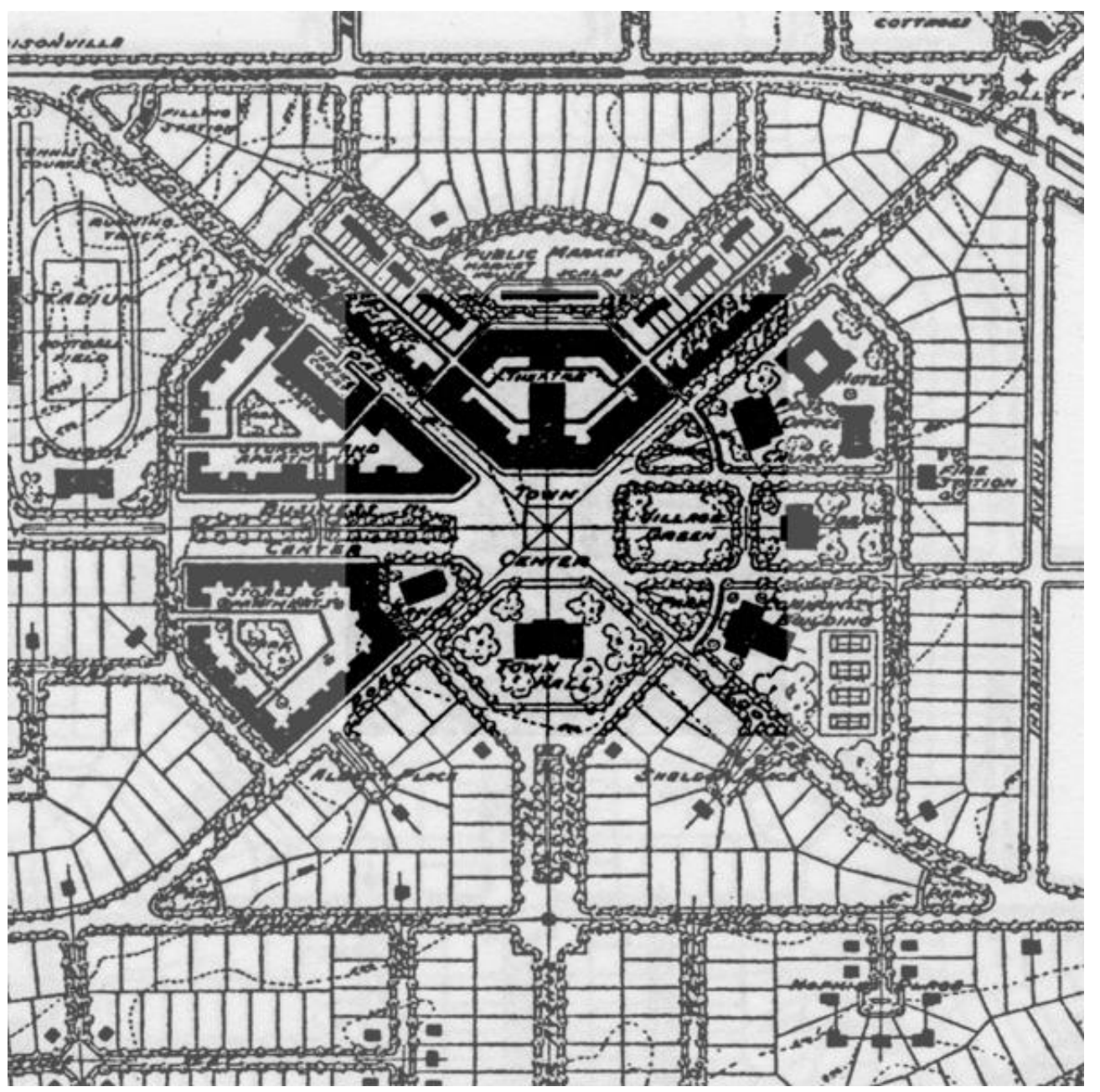

Figure 7. Mariemont "Town Center"

The third neighborhood unit in Mariemont centers upon the trolley station. This neighborhood is dominated by health care functions with a hospital, convalescent home, and housing for the workers at each (see Figure 8.)

23. O’Brien, “John Nolen and Raymond Unwin: Garden City Collaborators,” 2015. 


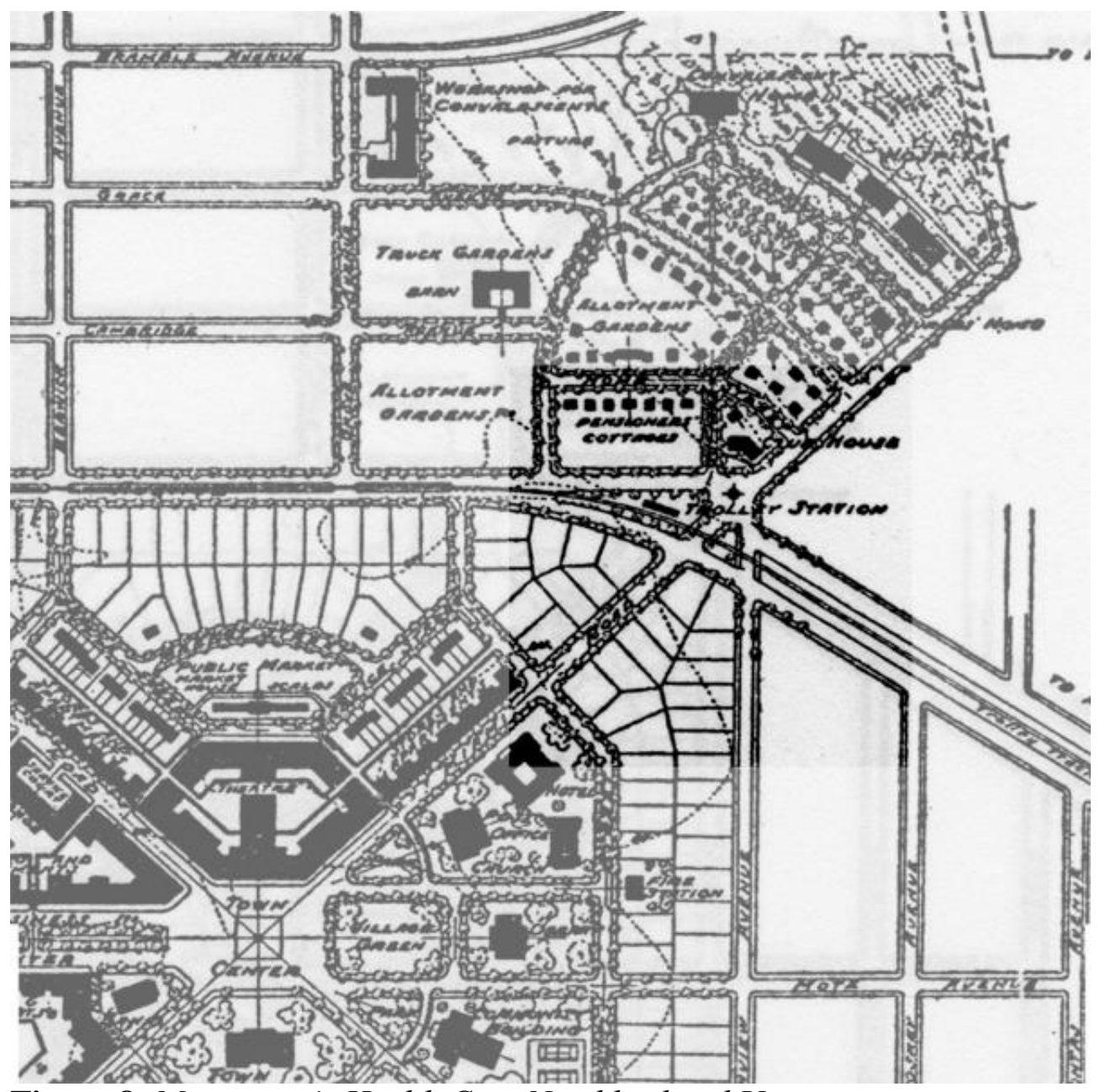

Figure 8. Mariemont's Health Care Neighborhood Unit

\section{Windsor Farms}

The Windsor Farms project was developed into 448 lots during the mid1920's on a 442-acre parcel immediately west of downtown Richmond, Virginia. John Nolen and Associates was hired by the T.C. Williams Development Company as planners and landscape architects for the project.

Unlike the highly advertised and publicized Mariemont, not many of Nolen's drawings for Windsor Farms survive to this day. ${ }^{24}$ Surviving drawings show two versions of the subdivision plan, a June plan and November 1924 revised plan. The plans are quite similar in structure with the street layout characterized by overlain diagonals and cross axial roads upon two strong concentric ovals with local institutions clustered around the town center,

24. Only two drawings (ink on linen) of the Windsor Farms development survive and are in the Nolen Collection of the Kroch Memorial Library at Cornell University. The first plan is dated June 1924 and a revised plan dated November 1924. The Nolen collection contains no correspondence referring to either the early plan, or the client's perceptions of strengths and weaknesses that resulted in the revised plan being developed. 
Windsor Common. The common is a green centered above the crossing of the axial roads (see Figure 9.) The site is located on a bluff overlooking the James River and is bounded by Carey Street on the North, South Locke Lane on the West, the James River bluff on the South, and route 76 / interstate 195 on the East (see Figure 9.)

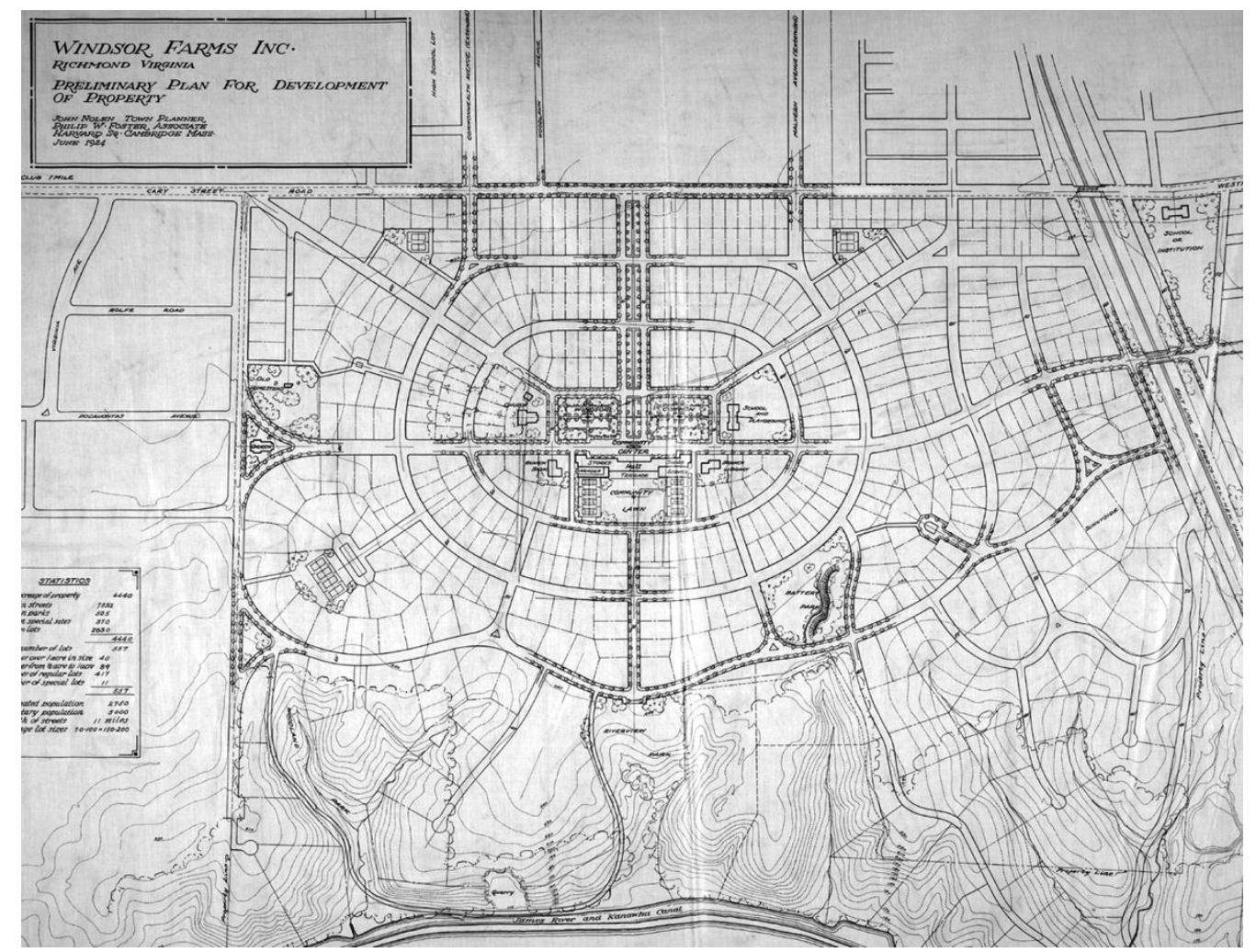

Figure 9. Windsor Farms June 1924 Overall Plan. Permission by Kroch Memorial Library (Accession 2903 Drawer 3 Rare and Manuscript Collection, Carl A. Kroch Library, Cornell University, Ithaca, New York.)

Like Mariemont, Windsor Farms is structured by Nolen's formal connection of the primary features of the site. Nolen connects Carey Street to the James River bluffs by extending a north-south boulevard from Carey Street to the green, Windsor Common. As at Mariemont, Nolen interrupts/ terminates the boulevard with the town center, Windsor Common, and its surrounding public buildings. The boulevard then continues toward the river bluff making the connection from the "back" of the green to the river overlook with a formally landscaped street, Wakefield boulevard. Also similar to Mariemont, an eastwest cross axis is developed along the back edge of the green. Two concentric oval roads overlay the cross axis and substantially fill out the site.

Unlike Mariemont, the Windsor Farms site was attached to an existing city structure. Nolen's design works to connect to the adjacent city with two devices, the northwest diagonal extending from Windsor Common to Carey street, visually terminating at an existing church, and the other a bridge from east-west axis across the expressway to the neighborhood beyond. 
Combined with these urban, natural and historic landmarks, the revised November plan includes places for five small parks, two schools, a church, small shops and a public hall. Of the fifteen public institutions ranging from parks to churches, libraries and two schools shown on the initial June plan, while only nine are included in the revised November plan. In both plans, these public institutions are generally treated as landmarks and visual terminations of axis to form neighborhood focal points.

Unlike his role at Mariemont, Nolen had little control over the programming and initial build-out at Windsor Farms. He expressed this concern to the developer T.C. Williams directly and indirectly to Henry Morse, a New Jersey Architect working on the house for T.C. Williams at Windsor Farms. In a letter to Henry Morse Nolen expressed concern for the architectural progress of the development as a whole. He complimented Morse on his work for Williams and sent him a brochure on Mariemont, citing it as an example of following through on the character of the plan (Nolen, 1926) Nolen was perhaps hoping Morse would advocate a controlled approach to style and design in Windsor Farms in the course of his conversations with T.C. Williams about the house. ${ }^{25}$

At Windsor Common, the subdivision's central space, a solid block identified as "stores" is shown on the western side, with a community "hall" in the center and "shops" on the eastern side. The importance of these neighborhood unit facilities is reinforced with the termination of the Windsor Way visual axis along the southern edge of Windsor Common. The center of this block, labeled as "hall" has a recess, roughly as wide as the Windsor Way Boulevard. This recess is the planner/landscape architect's suggestion to the future architect and builder that the massing of the "hall" should receive Windsor Way with a massing recess. The stores and shops adjacent to the central hall are wrapped slightly around the corners of the southeast and southwest diagonal roads. This is another suggestion from planner to, future architect/builder, as a reminder that the role of the corner is to compress the space, acting as a frame for the release to Windsor Common itself.

Neighborhood units such as this were frequently proposed by Nolen's office, but were less frequently constructed. This may be due to a misunderstanding between the developers expectation, i.e. Nolen will lay out streets and lots for residential neighborhoods, and Nolen's expectation, i.e. "this developer retained my firm to plan a neighborhood that will offer residents ready access to shops for daily needs, schools and churches." Mariemont has the strongest examples of constructed neighborhood units, while the many such centers shown on the various drawings for Kingsport Tennessee and Nokomis, Florida failed to materialize. At Windsor Farms even the significant reduction of the neighborhood unit between the June and November plans was not enough to insure its construction (Nolen 1922).

25. Letter from John Nolen to Henry Morse dated April 20, 1926 (Accession 2903 Box 66, Windsor Farms File, Rare and Manuscript Collection, Carl A. Kroch Library, Cornell University, Ithaca, New York.) 


\title{
The Demise of the Neighborhood Unit: The Suburb as Health Risk
}

\author{
The Neighborhood Unit Meets the Automobile
}

The success of Mariemont notwithstanding, Clarence Perry's ideals began to fall from favor with the development of the mega-suburban tracts following the Second World War. Levittown, with 17,311 homes in one tract, was developed by William J. Levitt started designing this iconic settlement with a focus on the efficiency of a factory, scaled for the car, not the pedestrian. ${ }^{26}$ Levitt successfully overcame location and amenity shortcomings with pricepoint and a direct appeal as a "Veterans-only" community. ${ }^{27}$ Levitt built minimal commercial and retail facilities, optimizing the land use towards the single family detached house, a decision that later caused homeowner tax rates to climb rapidly as there was effectively no commercial tax base.

Physically, Levittown is approximately two and a half miles square. Shopping is centralized, which places it a mile and a half from the development's periphery, too far to carry groceries without a car. The street layout had long loops stretching over 900 feet between intersections, compared to the Jeffersonian grid city with a 200 to 300 foot block length. These long loops mean that even if one lived within a quarter mile of shopping "as the crow flies," walking to the store would mean a walk of over a mile and a quarter, five times as far. The long loop streets also mean challenges controlling vehicle speed.

But Levittown was an enormous success in the eyes of real estate developers and the public. Its popularity among buyers led to its becoming an unfortunate prototype for the first-tier suburbs that would erupt across the country. Little did we know this land use pattern would become a contributing factor to the $21^{\text {st }}$ century public health crisis of obesity, diabetes, hypertension and cardiac disease among young and old alike.

Following the explosion of Levittown-like developments across America between 1947 and 1981 when a small new town was developed on the Florida coast. Seaside Florida quickly became the national exemplar for what was called the "New Urbanism" which favored a return to many of the principles Pioneered by Clarence Perry in the 1920's. ${ }^{28}$

The Charter of the New Urbanism favored the neighborhood as the identity element for residents. Yet the town center concept would have required significant capital investment in utility infrastructure, private retail facilities, and supporting public service facilities. While the neighborhood unit concept holds tremendous opportunity to help promote a walking culture, the scale at which retail becomes even modestly profitable precludes placing retail, and thus healthy foods, within the 5-minute walk Clarence Perry recommended.

26. J. Peltz, It Started with Levittown in 1947: Nations 1st Planned Community Transformed Suburbia (The Los Angeles Times, 1988.) http://lat.ms/2vAy2QS. [Accessed 31 January, 2017].

27. Ibid.

28. D. A. Rodriguez, A. J. Khattak and K. R. Evenson, "Can new urbanism encourage physical activity?: Comparing a new Urbanist neighborhood with conventional suburbs," Journal of the American Planning Association 72, no.1 (2006): 43-54. 
As early as 1999 The Charter for New Urbanism posited a connection between neighborhood design and sedentary lifestyles. ${ }^{29}$ This was one of the early connections between environment and health, supported by the 1996 Report of the Surgeon General of the United States that found $60 \%$ of Americans were not physically active. ${ }^{30}$ The Surgeon General's report goes on to list the following as disease and injuries for individuals that could be reduced with modest increases in daily physical activity. ${ }^{31}$

- Cardiovascular Disease

- Colon Cancer

- Diabetes

- Osteoarthritis

- Osteoporosis

- Falling

- Obesity

The report went on to say "efforts must be made to encourage physical activity within the course of the day and to create environments in communities, schools, and workplaces that afford maximum opportunity to be active."32 At the time of this writing, 2017, the Surgeon General's call to make the environment a supportive force in the prevention of sedentary related diseases remains largely unheeded.

Without Clarence Perry's Neighborhood Unit, we have become tied to our automobiles to undertake even the simplest shopping tasks. Perhaps the time has come to re-envision the Neighborhood Unit in a contemporary way.

Recently, temporary pedestrian spaces have been installed in many cities without purchasing land or making substantial capital improvements. These "micro parks" or "parklets" offer the potential to reclaim a bit of automobile territory in service of the neighborhood. Section "Social Media Enabled Micro Retail: A Proposal to Renovate the American Landscape" of this paper will examine "parklets" in more detail and consider their role in the delivery of goods and services within an easy walk of most residents.

29. M. Leccese and K. McCormick, "Charter of the new urbanism. essays by Randall Arendt and others," (ed.) Michael Leccese and Kathleen McCormick (New York: McGraw Hill, 2000), 64.

30. U.S. Department of Health and Human Services. Physical Activity and Health: A report of the Surgeon General. Atlanta GA: U.S. Department of Health and Human Services, Centers for Disease Control and Prevention, National Center for Chronic Disease Prevention and Health Promotion 1996.

31. Ibid, 6.

32. Ibid, 240. 


\section{Health and Population: Brazos County and Bryan, Texas Case Study}

Renovation of the suburban landscape is a capital-intensive activity, fraught with policy and legal issues surrounding private property rights. While there are legislative tools available to policymakers such as condemnation, eminent domain, tax increment financing districts, overlay zoning ordinances and so on, these are infrequently used in the cause of public health. Like other issues involving the environment and health, the obesity epidemic is still largely viewed as a personal responsibility problem, not something public tax dollars need to address.

Researchers conducting rigorous empirical methods have compared the more walkable "New Urbanist" type neighborhoods with more auto-oriented neighborhoods and have shown that after correcting for age and income, residents of walkable neighborhoods make fewer automobile trips per day, spend more hours per day being physically active, make more walking or bicycling trips and fewer car trips per day resulting in more hours per day of moderate and vigorous physical activity. ${ }^{33}$

In the 2006 study of neighborhood design and resident physical activity, Rodriguez concluded, "new urbanism's support for physical activity obtained through utilitarian travel may be important for groups with lower incomes."

Bryan, the county seat of Brazos County in Texas is a case example for this paper. The population of Bryan stood at 11,842 in 1940, and is 78,209 today. ${ }^{34}$ The population boom coincided with the grown of the railroad, local industry, and Texas A\&M University. Much of the growth followed the Levittown model of automobile-oriented suburban growth leading to a slow abandonment of the central downtown district that has only recently been revitalized.

The 2013 Regional Health Assessment for Brazos County ${ }^{35}$ noted that community groups cited transportation as a key issue, as was the lack of access to affordable healthcare. The report also notes:

- The Federal poverty level for 2012 was $\$ 23,050$ for a family of $4,9 \%$ of respondents reported incomes at or below FPL.

- $17.6 \%$ of respondents had incomes between 101 and 200 percent of FPL, making them low income.

- "Almost one in three respondents reported some interruption of the usual activities (due to poor physical or mental health) with $18.5 \%$ indicating between one and five days, $3.5 \%$ reporting six to 10 days, and 7.2 percent reporting more than 10 days" (p. 13.)

33. Rodriguez, Khattak and Evenson, "Can new urbanism encourage physical activity?: Comparing a new Urbanist neighborhood with conventional suburbs," (2006): 43-54.

34. Texas Almanac, http://bit.ly/2jfYh9D. [Accessed February 27, 2017].

35. RHP 17 Regional Health Assessment 2013 Supplemental Report: Brazos County. Prepared by Center for Community Health Development, Texas A\&M Health Science Center, School of Rural Public Health (p.3). 
- "The most commonly reported impairment or health problems were related to joint and bone health issues - back or neck problems comprised $14.6 \%$ of responses followed by arthritis/rheumatism (13.9\%) and fractures. A substantial portion of responses were also related to cardiovascular health $(8.9 \%)$ (p.14.)

- "Disturbingly, nearly one-quarter of the participants $(22 \%)$ did not feel very healthy and full of energy for at least one-third of the month, and an additional 12.7 percent reported never feeling healthy or full of energy" (p. 15.)

- "Being overweight or obese increases an individual's risk for developing many chronic diseases and other conditions such as depression and chronic pain" (p. 15.)

- "In Brazos County, only $37.1 \%$ of respondents were assessed to be at normal weight for their height. Nearly one-half of the survey respondents were overweight or obese; one-third were overweight (33.8\%), nearly one in seven was obese (13.6\%) and alarmingly, the same percentage were morbidly obese. Given the number and types of (health) conditions that are related to obesity, these statistics are a cause for concern in this community" (p. 15.)

- "The mean distance Brazos county residents travel to buy groceries is 4.3 miles."

- "Physical activity is also a key aspect of maintaining a healthy and weight and good health. The National Institutes of Health recommend 150 minutes of moderate or 75 minutes of vigorous physical activity each week, in addition to engaging in strengthening exercises twice weekly." Across Brazos County, only $28.7 \%$ of respondents meet this recommendation, while 17.2 percent reported they rarely do any physical activity."

- "In a seven-day period, respondent's reported sitting an average of 388 minutes (6.5 hours) on weekdays and 321 minutes (5.4 hours) on weekends" (p. 16).

- The six most frequently reported Chronic diseases and conditions were:

$\begin{array}{ll}\text { oHypertension (high blood pressure) } & 29.5 \% \\ \text { oDepression } & 27.3 \% \\ \text { o Obesity/Overweight } & 26.8 \% \\ \text { oHigh Cholesterol } & 26.3 \% \\ \text { o Anxiety } & 24.7 \% \\ \text { o Asthma } & 19.6 \%\end{array}$

- "Transportation continues to pose a formidable challenge for all segments of the population and can be a significant barrier when it comes to accessing health care and related services" (p.23.)

- "Community Issues: Survey respondents were asked to rate the severity of a list of community issues, on a scale ranging from not at all a problem to a very serious problem. In Brazos County, the top 10 
issues rated as a serious problem or a very serious problem were as follows:

1. Illegal drug use $(30.7 \%)$

2. Alcohol abuse $(29.3 \%)$

3. Poor or inconvenient transportation $(27.4 \%)$

4. Risky Youth behaviors (26.9\%)

5. Teen pregnancy $(24.4 \%)$

6. School dropout $(22.6 \%)$

7. Poverty (22\%)

8. Lack of jobs for unskilled workers (18.5\%)

9. Unemployment (18.3\%)

10. Access to affordable healthy food (15.9\%)

Walkscore.Com rates Bryan, Texas as a "car-dependent" city. ${ }^{36}$

\section{Social Media Enabled Micro Retail: A Proposal to Renovate the American Landscape}

This paper is proposing a network of mini-parks, "parklets" spaced within a 5-minute walk of neighborhoods, all across the case study city, Bryan, Texas as neighborhood places for the delivery of goods and services.

Low-Intensity Capital Development:

The "Parklet" and "Streateries"... the Popup Plaza:

The Oxford English Dictionary defines a "parklet" as "A small seating area or green space created as a public amenity on or alongside a pavement, especially in a former roadside parking space."

The curbside park, the "parklet" could become a small-scale neighborhood public place made a few parking spaces along a street. "Parklets" 37 have been built in cities around the world as both permanent and temporary public spaces as often happens in annual PARK(ING) Day events around the world. ${ }^{38}$

As such, "parklets" are fairly recent phenomena, seen more in major urban areas, but are a "capital-investment-lite" approach to retasking a bit of streetside parking for use by pedestrians (see Figure 10.) The "parklet" is frequently one to two parking spaces that have been flagged off from the street to protect the pedestrians, and decked over to bring the surface elevation to curb elevation, then populated with chairs, tables, planters, sometimes even overhead shade and arbors. The temporary construction of "parklets" have been championed by San Francisco's Rebar Associates

36. Walk Score. https://www.walkscore.com/TX/Bryan. [Accessed March 1, 2017].

37. M. Birdsall, "“"parklets:” Providing Space for People to Park... Themselves," ITE Journal 83, no. 5 (2013): 36.

38. J. Greco, "From Pop-Up to Permanent," Planning 78, no.9 (2012): 14-18. 
"PARK(ing)" day, held world over on the third Friday of September since 2005. Documentation of PARK(ing) day shows the great variation in the design of the 850 "parklets" around the world. ${ }^{39}$

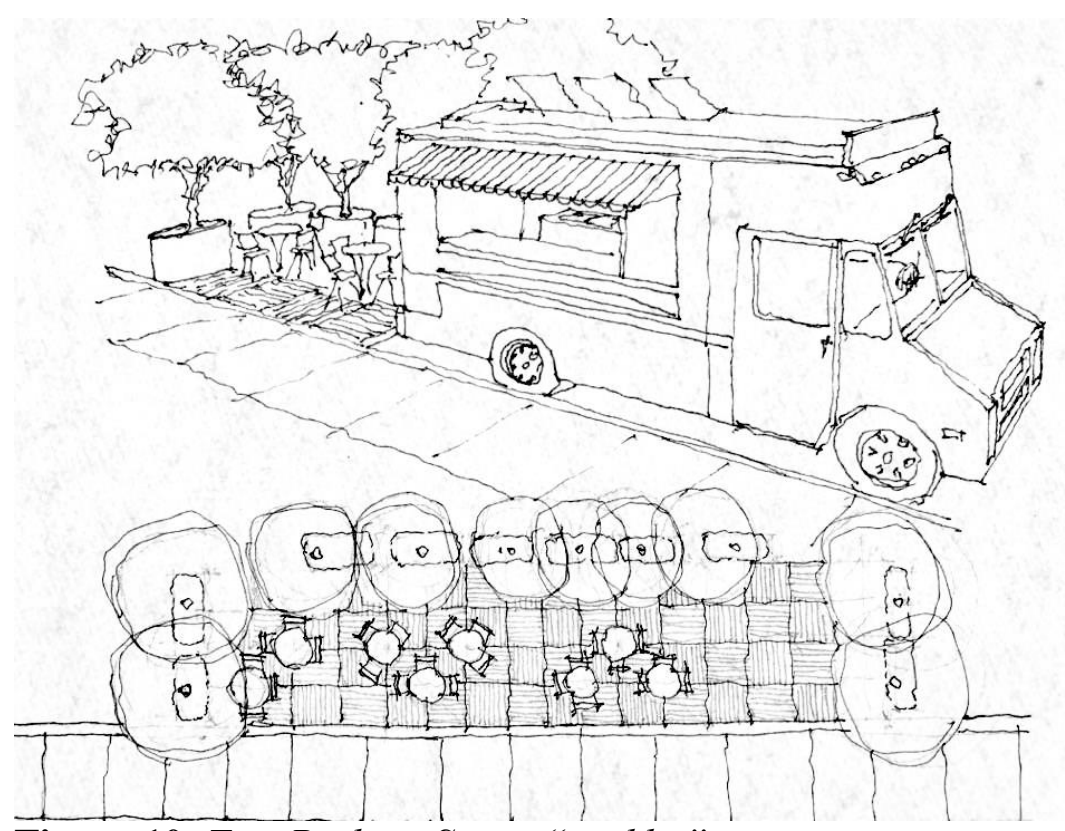

Figure 10. Two Parking Space "parklet"

The costs to a "parklet" sponsor become limited to:

1. Temporary barriers and seating (planters (shown) or "Jersey" barriers.)

2. Pallets to make a surface near curbside height for accessibility.

3. Shade (leased or donated or city grown, could fabric too.)

4. Insurance.

In addition to sponsorships, "parklets" could be financed by crowd-funding, community service clubs, built with pro-bono or in-kind services, community block grants, or as a part of a larger infrastructure bond issue.

A slightly larger version of the capital-lite approach to developing the public realm is what is called the "Popup Plaza." The Popup Plaza might be an empty lot in the neighborhood, or the parking area of a vacant building. While being larger than the "parklet," the popup plaza would have an all weather surface capable of supporting farmers market stalls and vehicles, vendor trailers, food trucks, etc. and would be furnished with tables, chairs planters etc. and may even include a small stage for street performers. The popup plaza, like the "parklet," would be programmed/scheduled with vendors and service providers, but the durations would be longer, instead of the 30 to 45 minute vendor presence at a "parklet," durations might be a full activity period, 4 hours in the morning, or 4 hours over noon, or evening, etc.

39. G. Coombs, “park (ing) day,” Contexts 11, no.3 (2012): 64-65. 
To be successful and to serve neighborhood residents, the "parklet"/popup plazas must be conveniently located within a 5-minute walk, must have an identity in the neighborhood and in the network of neighborhoods, and must be actively scheduled, with vetted, dependable vendors (see Figure 11.)

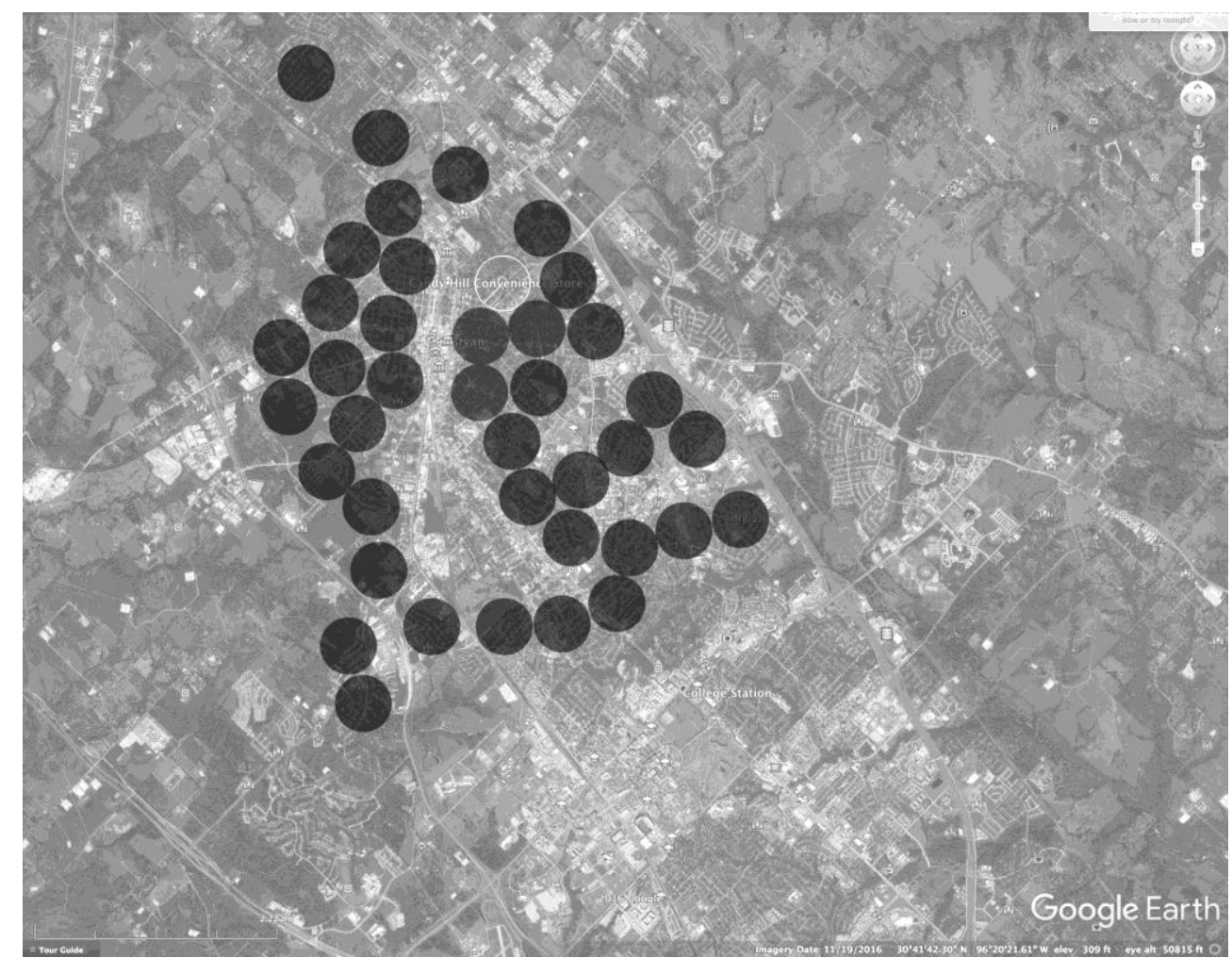

Figure 11. Series of 5-minute Walking Radius Circles Overlaid on the Residential Districts of the City of Bryan, Texas

The environmental impacts of the development of 42 parklets across the 28,480 acres making up Bryan, Texas should be considered not simply from the cost perspective of the initial construction, but from the social benefits to the neighborhoods. Many of the residents of Bryan's neighborhoods have no identity element to associate themselves with. Schools have become more centralized and less neighborhood-centric, parks are few, and municipal investment at the neighborhood scale in public amenities is relatively rare. These 42 parklets would give each neighborhood an identity element, someplace they are "from," a reference to offer to outsiders as well as a place for the delivery of micro-scaled goods and services. The impact on parking area occupied by these parklets is minimal, 84 out of the thousands that line the streets of the city. The impact of shading from landscape at the parklets could only be considered beneficial, considering the high temperatures the city experiences throughout the spring and summer. Similarly, the impact of these parklets on flooding will be minimal as the space beneath the parklets is currently paved, nonporous and thus any water held by the parklets planters would reduce the urban flash flooding risk, if only by an infinitesimal amount. 
In the case of both "parklets" and popup plazas, ongoing costs to suburban government might only be the cost of a citywide micro-economic developer, and vendor coordinator, but could also become a "parklet"/popup plaza sponsor itself.

The role of the city's micro-economic developer would be to educate and assist vendors interfacing with health departments and other city/state agencies to obtain the necessary training, permits and inspections to operate their small business. The micro-economic developer, as a vendor advocate, also helps vendors interface with financial institutions and the Small Business Administration to find financing, mentorships, and develop business management skills. Suburban governments might go farther, establishing their own loan/equipment pool program to help bootstrap a new vendor into a tricycle, a pickup truck or food truck or trailer. Local service organizations might be recruited into this effort through their missions or projects for economic development, public health, or community well-being.

The Problem of Scale in Retail Grocers:

Why not build more Grocery Stores in Walking Distance to Neighborhoods?

In their 2004 paper "Accessibility versus Scale" Dunkley, Helling, and Sawicki found that retail stores were larger in newer developments, and larger in higher income areas. ${ }^{40}$ They concluded that affluence did not correspond with closer proximity to the grocery, that longer trips to the grocery store were related to mobility enabled by affluence. ${ }^{41}$ They further noted that while smaller stores can succeed in being profitable, the smaller retail establishments, perhaps more appropriate to a neighborhood scale, needed to differentiate their goods and services in the market. Their data further pointed to mobility (the percentage of households having no automobiles) as a key factor, and that public policy favoring small grocery stores would be most effective in areas where residents had "restricted mobility."

But, again, the expense of a public investment to "buy out" private property and offer inducements to place a small grocery store in lower income neighborhoods is a significant obstacle to employing public policy alone to establish small grocery stores and "neighborhood units."

To recap, at this point we have identified the problem factors, and our proposition in response is to develop places within the 5-minute walk proposed by Perry where residents could walk to purchase their daily necessities. These places could also deliver health care screening, limited social service support, and cultural programs.

40. B. Dunkley, A. Helling and D. S. Sawicki, “Accessibility versus scale: examining the tradeoffs in grocery stores," Journal of Planning Education and Research 23, no.4 (2004): 387401.

41. Ibid, 399. 
Twitter, "Parklets" and Popup Plaza's the Cure for Suburban Disease?

All that is needed is a means to let the neighborhood know what services or goods will be offered in their "parklet," and the time duration of the service or goods availability. This information could be offered by being "pushed" from the vendor to the resident, or by being "pulled" by the resident from the vendor. The real-time nature of many social media platforms makes both modes possible.

\section{Overcoming the Problems of Brick and Mortar Facilities for Retail and} Service Providers

The Food Truck is an example of a business that breaks the norm for the suburban model of service and goods providers. While brick and mortar franchises still dominate the retail strips of suburbs around the country, an alternative model, a mobile model, the food truck, is taking hold.

As a business, a food truck is relatively easy to start. ${ }^{42}$ A modest truck operation may cost as little as $\$ 50,000$, which, when compared to the cost of starting a franchise food brick and mortar facility is $95 \%$ less expensive. ${ }^{43}$ But a brick and mortar franchise has an advantage over the food truck, a known location. Through print and street signage advertising, brick and mortar businesses make themselves known to the public, thus the competition and also higher prices for locations that have higher visibility i.e. more traffic "eyes" on the location each day. Food Truck businesses have this visibility problem as an inherent characteristic of their business. Economists call this "locational friction."

Economists use the term "friction" to describe the disadvantage some characteristic that a business has to overcome in the mind of the consumer in order to capture that consumer's business. ${ }^{44}$ In their article "How Smartphones and Social Media Dialed Up the Food Truck Boom and Increased Access to Food Variety" Anenburg and Kung found that "locational friction" that is, being located inconveniently to consumers, was overcome in the specialty food industry by moving out of brick and mortar facilities and into mobile food trucks. The friction was further reduced through the use of social media to announce the time, place, and sometimes the menu that would be available. Anenburg and Kung constructed sophisticated models and subjected the Twitter feeds of various food truck businesses and found that their problem of "how will a customer know where we will be located" is effectively addressed through their use of social media to tweet and post their routes and schedules for a given day. Social media "relaxes" locational friction in the authors'

42. Investopedia contributor. The Cost of Starting a Food Truck, Forbes Magazine, PAGES, 2012. http://bit.ly/2hLO5Fd. [Accessed February 20, 2017].

43. Google citation on the cost of starting a Mcdonalds franchise requiring 1-2.2 million dollars compared to the cost of a modest food truck startup of $\$ 50,000$.

44. E. Anenberg and E. Kung, How Smartphones and Social Media Dialed Up the Food Truck Boom and Increased Access to Food Variety, 2014. 
findings. They also found that the consumer benefit to social-media-enabledenterprise is the satisfaction of consumer demand for variety, and the related growth in food truck businesses. They caution that further research is necessary to further validate the relationship between social media and business success in the mobile food service retail sector.

Three-wheeled bicycle food carts further reduce the capital cost to begin a business. "Wheelys," an international franchise and producer of the "bicyclebased-café" promotes their mobile food franchise as a way to change one's life for approximately $\$ 9,000.00$. $^{45}$

Feasibility: Immediately, One Asks, "Where? Who Pays? How can it Succeed?"

Given the contemporary focus on profitability as the measure of feasibility, one might ask, "who will profit from activity like this?" This question might be restated as "who makes money when we are healthier?"

Perhaps large employers have a substantial interest in this context. Healthier employees could mean lower insurance costs to both employee and employer. Employers already screen and differentiate cost of health insurance to employees based on tobacco use and on employee participation in annual health care screenings, is body mass index next?

Perhaps health insurance companies are also an interested/profiting party and potential partner. A project such as this, establishing places for daily food needs within five minute walks of 80,000 or so residents might mean 80,000 people walking $1 / 2$ mile each day that translates into 3 miles or more per week, or 240,000 person-miles. That alone must translate into good market exposure ("We just do not pay when you get sick, we help you stay healthy.")

Another potential interested party/partner might be the major grocery outlets. These outlets currently sponsor many community events, contributing food, water, and various supplies. If there was a network of neighborhood "parklets," multi-service grocery stores could promote their consumer health departments through blood pressure, glucose, cholesterol, and diabetes screening held at the "parklet." This would perhaps reach more potential customers than those whose shopping day corresponds with in-store screenings. Flu shot clinics, back to school inoculation clinics within a five-minute walk of home could have significant marketing benefits for their brick and mortar locations. Social services could be another significant community partner and advocate, delivering food pantry, well-child, and clearinghouse advice on sources of care and services.

\section{The "Parklet" as an Economic Development Engine}

Another segment of advocacy for the neighborhood "parklet" might be the local economic development agency. Imagine being able to incubate hundreds of

45. Wheelys 5 Open Source: A Revolutionary Bike Cafe. (2016, November 1). https://www indiegogo.com/projects/wheelys-5-open-source-bike-cafe-x7-coffee-community\#/. [Accessed February 20, 2017]. 
new businesses that would focus on the delivery of goods to the neighborhood unit/"parklet" network. If the business began with one employee on a freight tricycle, expanded to a pickup truck or motor scooter, then to a truck-based business, and perhaps then to a kiosk or brick and mortar location, each business might grow from one to five or six employees.

- Home Based Food Services

- Coffee Cart

- Farmers Markets

- Florist

- Craft sales

- Bicycle Repair

- E Bay Assistant

- Flea Market

- Tax Preparer

- Bookseller/Bookbuyer

- Tutoring

- Software Training

- Sewing and Alterations

Say each business day cycle needed a morning presence a noon hour presence, a dinner hour presence, and an evening presence, four periods of activity at each neighborhood unit. An 80,000-person town spread across 30,000 acres might have need for over 125 "parklets." 46 This seems extreme at first. If one is only able to think of the neighborhood unit as a brick and mortar store for each vendor, it is extreme... extremely expensive... and unlikely to be sustainable.

\section{The Problem in Three Factors}

This leads us to the problem, if (1) physical activity is known to reduce or potentially prevent debilitating (and expensive) disease, and if (2) the free market nature of the American suburb precludes government from making sweeping changes in neighborhood form and function ${ }^{47}$, and if (3) the profitability of

46. 30,000 acres $/ 120$ acre service areas $=250$ neighborhood units. Assume only $50 \%$ of these would fall outside of existing commercial, industrial zones, 125 neighborhood units or "parklets" would fall within residential zones. A freight tricycle might take 6 minutes to travel from one service center to another so a tricycle vendor might be able to spend 30 minutes per activity cycle (morning, noon, afternoon, evening) per neighborhood unit and serve 4 or more neighborhood units. If there were 125 neighborhood units, 46 or more vendors of a given product type (ice cream, coffee, etc.) might be needed to cover all the neighborhood units. There may be demand for unprepared food vendors (farmers market vendors, fish vendors, fresh egg vendors) as well as prepared food vendors (coffee, sandwiches, desserts) and product vendors (florists, delivery) perhaps resulting in over hundreds of vendor/ jobs created.

47. Large U.S. cities and the U.S. Department of Housing and Urban Development (HUD) under the Housing Acts of 1949 and 1954, had undertaken extensive demolition and reconstruction projects from the 1930's through the 1970's to remove deteriorated neighborhoods 
contemporary retail requires large central locations (auto oriented) then how can the existing suburban fabric be renovated to encourage walking for utilitarian (purchase of necessary goods and services) purposes?

\section{Site Studies}

\section{The Candy Hill Neighborhood, Bryan, Texas}

The Candy Hill Neighborhood is located North of downtown Bryan, Texas and is bounded by Waco Street on the North, Military Drive on the South, The Bryan City Cemetery on the West, and the Federal Prison Camp on the East. The neighborhood is approximately 62 acres in area, was developed in the mid 1970 's, and is generally flat with scattered street and neighborhood yard trees. The center of this neighborhood is only one mile from the "downtown" area of Bryan, but like many older downtowns, one cannot purchase groceries, or visit a doctor as those functions have long since relocated away from the downtown area. $^{48}$ (See Figure 12.)

Median income in the Candy Hill neighborhood is $\$ 27,743.00$ and $10 \%$ of the residents self identify as college educated. Over $70 \%$ of the housing in the neighborhood is owner-occupied and $63 \%$ of the residents are married. Onequarter of the residents make a commute to work of less than 25 minutes, and $60 \%$ of the unmarried population is Male. ${ }^{49}$ While the greater Bryan city area has a higher crime rate than the U.S. average, the Candy Hill Neighborhood reports few instances of criminal activity.

and replace them with contemporary housing and public use projects under the "Urban Renewal" title. Reduced ethnic, income, functional and social diversity often resulted and left cities with a more auto-dependent infrastructure.

48. Google earth V. 7.1.8.3036, (1/17/2017). Bryan, Texas, USA, 3040’55’N, $96^{\circ} 21^{\prime}$ 96”W, Eye alt 7587 feet. http://www.earth.google.com [March 20, 2017].

49. Neighborhood demographics. https://www.trulia.com/real_estate/Candy_Hill-Brya n/12136/community-info/. [Accessed March 20, 2017]. 


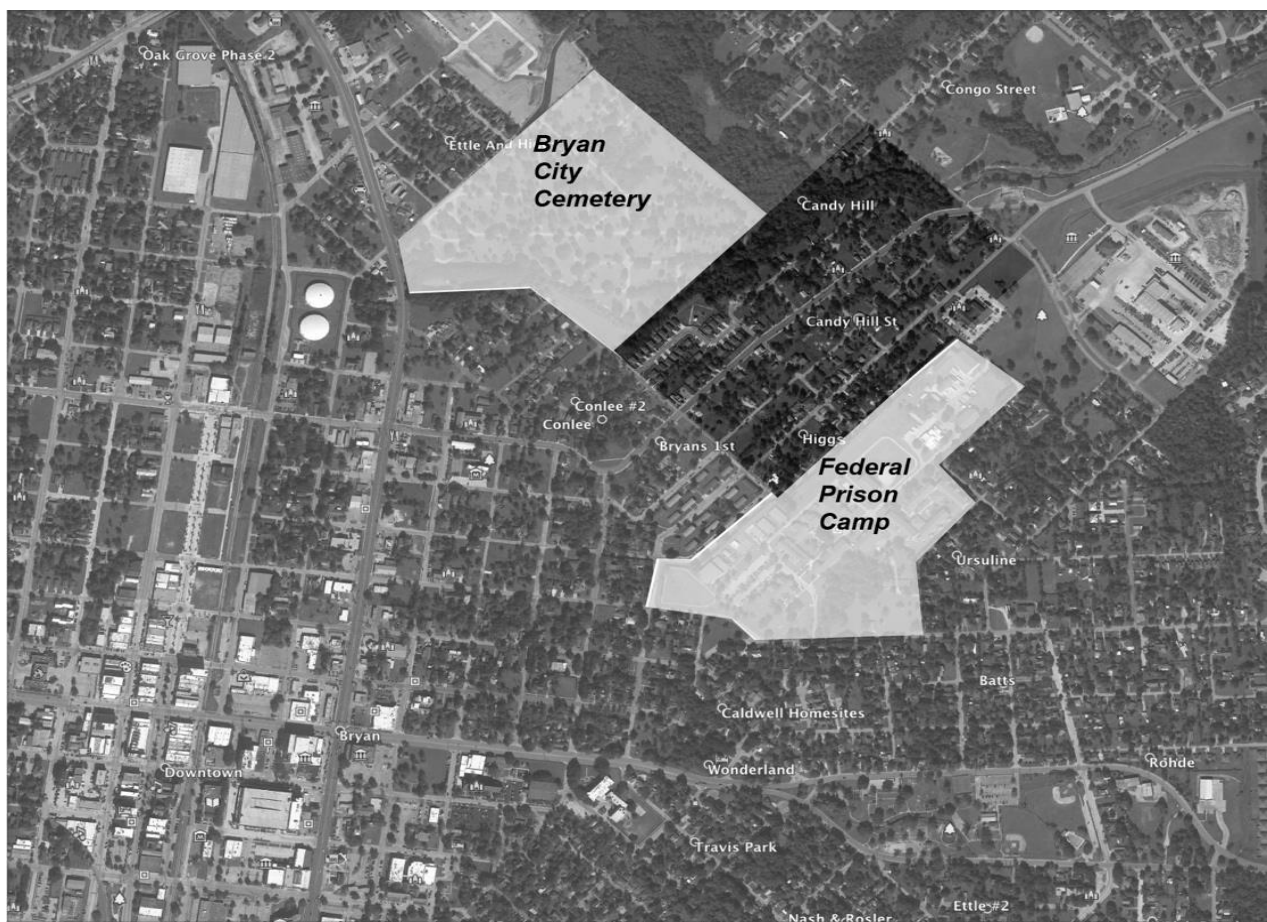

Figure 12. Candy Hill Neighborhood in Bryan Texas, Location between Cemetery and Federal Prison

The closest full-service grocery store is approximately 1.5 miles away, and the nearest medical facility is approximately 2.0 miles away.

How far will people walk in the Candy Hill neighborhood? In 1929, Clarence Perry proposed 5-minute (quarter mile/.4K) was as far as most people would want to walk for goods and services, and this seems to hold true today as a general rule for planners. ${ }^{50}$ Perry formulated that principle in the context of the cities of the Northeast where the weather was mostly walkable. In Bryan, Texas, the 5-minute walk in summer is likely to take place in 80 to 105 degree farenheit ( 26 to $40 \mathrm{C}$ ) and in humidity that might range from 50 to $85 \% \mathrm{RH}$.

The United States Environmental Protection Agency lists this combination of temperatures and humidity as "caution" to "danger" of heat-related disorders "with prolonged exposure or strenuous activity." The effect of heat and humidity varies with age, gender and an individual's acclimatization to the exposure. ${ }^{51}$ In urban plazas, and in walking to and from plazas, we are more concerned with the perception of comfort in people than simple temperature and humidity charts. Mayer and Hoppe (1984) developed a model to measure human comfort that accounted for metabolic, radiative, conductive modes of heat transfer experienced by people. Their model, the Munich Energy-balance

50. R. Donahue, Pedestrians and park planning: How far will people walk. City Parks Blog, 2011.

51. A. Coco, B. Jacklitsch, J. Williams, J. H. Kim, K. Musolin and N. Turner, Criteria for a Recommended Standard: Occupational Exposure to Heat and Hot Environments. http:// bit.ly/2hYlEba. [Accessed March 20, 2017]. 
Model for Individuals, (MEMI) is the basis for arriving at the Physiological Equivalent Temperature (PET.) ${ }^{52}$ While studies by Thorsson et al (2007) show that Japanese residents preferred shaded areas of parks and plazas when temperatures rose above 68 degrees farenheit (20C) research establishing "comfortable" walking distances at high temperatures, high humidity and low wind-speeds are difficult to find. ${ }^{53}$ Personal experience (mine) tells me that a home-to-destination distance of 5-minutes, yielding a 10 minute round trip, at typical summer temperatures/humidities/windspeeds will usually result in extreme perspiration, significant enough to become a strong disincentive to walk (see Figure 13.)

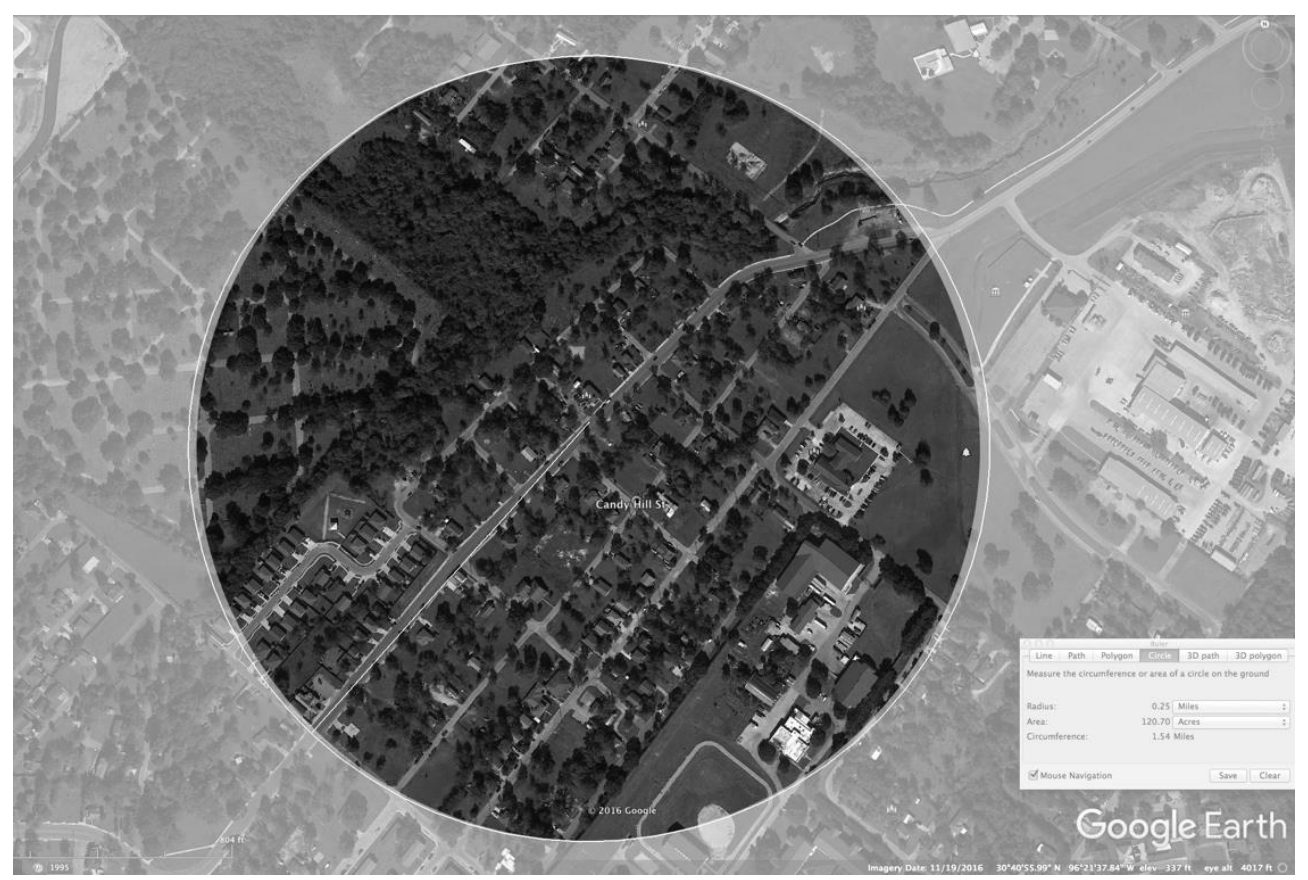

Figure 13. The 5-minute Walk Radius Overlaid upon the Candy Hill Neighborhood

Figure 13 shows that a 5-minute walking radius easily encompasses the neighborhood. The next step might be finding a location for our proposed "parklet." The center of the radius falls on the "New Direction Worship Center" Two parking spaces across the street from the Worship Center would be an ideal site for the "parklet" as there are no businesses nearby that might be concerned about competition and the Worship Center is already a community service type of organization. This possible "parklet" location is also on a lowspeed street, $30 \mathrm{mph}(48 \mathrm{KpH}$,) and has a public sidewalk adjacent to the street.

Drawbacks to the location are the shortage of shade, requiring some shading device or more substantial portable planters, and a nearby driveway which

52. S. Thorsson, T. Honjo, F. Lindberg, I. Eliasson and E. M. Lim, "Thermal comfort and outdoor activity in Japanese urban public places," Environment and Behavior, 2007.

53. Brown, Robert, (Personal Communication.) March 22, 2017. 
would have to remain unobstructed, but a two-parking space "parklet" would be physically possible on the site.

At this time, Bryan, Texas has no regulations governing the process, sititng, setbacks, construction or management of "parklets." Many cities across the United States have developed design guidelines and helpful manuals to assist residents in the safely locating, constructing and operating a "parklet." San Francisco, Philadelphia, and Minneapolis are among the major cities with such manuals and regulations but even smaller cities like Bethlehem, Pennsylvania are providing residents support for "parklet" development.

Parklets have the potential to re-invigorate neighborhoods while they serve as an access point for healthy foods, health screening, and a wide variety of retail goods and services. Taken at the scale of a city, "parklets" can become a network, and spur micro-scale economic development generating dozens, perhaps hundreds of tiny businesses while becoming one more part of the "vitality equation" so critical for smaller cities and their residents to thrive.

Taken as a whole, parklets have the potential to enhance our daily exercise, build neighborhood identity and cohesiveness, support a "micro" economy making business opportunities for entrepreneurs with little or no capital, and making a network of public spaces throughout cities. Parklets would contribute to the "slowness" of the city by bringing local foods to the citizens, by being a venue for local storytellers and musicians, and bringing down the scale of the street, to something a bit more manageable and personable, thus contributing to what Jan Gehl as "the $5 \mathrm{~km} / \mathrm{h}$ " streetscape. ${ }^{54}$

\section{Acknowledgments}

My thanks to "The Department of Architecture at Texas A\&M University" for allowing release time to develop this paper.

\section{Bibliography}

Anenberg, E. and E. Kung. How Smartphones and Social Media Dialed Up the Food Truck Boom and Increased Access to Food Variety, 2014.

Birdsall, M. “"Parklets:” Providing Space for People to Park... Themselves." Institute of Transportation Engineers. ITE Journal 83, no. 5 (2013): 36.

Byun, N. Y. Choi and J. Choi. "The Neighborhood Unit: Effective or Obsolete?" Journal of Asian Architecture and Building Engineering 13, no.3 (2014): 617624.

Coco, A., B. Jacklitsch, J. Williams, J. H. Kim, K. Musolin and N. Turner. Criteria for a Recommended Standard: Occupational Exposure to Heat and Hot Environments. http://bit.ly/2hYlEba. [Accessed March 20, 2017].

54. J. Gehl, L. Kaefer, S. Reigstad, "Close encounters with buildings," Town Planning And Architecture 29, no.2 (2006): 70-80. 
Comey, Arthur C. "Neighborhood units." In City Planning: A Series of Papers Presenting the Essential Elements of a City Plan. Edited by John Nolen. New York and London: National Municipal League Series, D. Appleton and Company, 1916.

Comey, Arthur C. Transition zoning. Cambridge: Harvard University Press, 1933.

Coombs, G. "park (ing) day." Contexts 11, no.3 (2012): 64-65.

Donahue, R. Pedestrians and park planning: How far will people walk. City Parks Blog, 2011.

Dunkley, B., A. Helling and D. S. Sawicki. "Accessibility versus scale: examining the tradeoffs in grocery stores." Journal of Planning Education and Research 23, no.4 (2004): 387-401.

Gehl, J., L. Kaefer, S. Reigstad. "Close encounters with buildings." Town Planning and Architecture 29, no.2 (2006): 70-80.

Greco, J. “From Pop-Up to Permanent." Planning 78, no.9 (2012): 14-18.

Harris, B. "Planning the great metropolis: the 1929 regional plan of New York and its environs." Environment and planning B, Planning and design 25, no.1 (1998): 486-498.

Holzner, L. "Camillo Sitte: The Birth of Modern City Planning with a Translation of the 1889 Austrian Edition of his City Planning Artistic Principles." Book Review 19, no.2 (1988): 89.

Investopedia contributor. The Cost of Starting a Food Truck. Forbes Magazine. PAGES, 2012. http://bit.ly/2hLO5Fd. [Accessed February 20, 2017].

Jacobs, J. The death and life of great American cities. New York: Random House, 1961.

Leccese, M. and K. McCormick. "Charter of the new urbanism. Essays by Randall Arendt and others." Edited by Michael Leccese and Kathleen McCormick. New York: McGraw Hill, 2000, 64.

Mayer, H. and P. Höppe, P. "Thermal comfort of man in different urban environments." Theoretical and Applied Climatology 38 (1987): 43-49.

Nolen, John. City planning: a series of papers presenting the essential elements of a city plan. $2^{\text {nd }}$ Edition. Edited by John Nolen. New York; London: D. Appleton and Company, 1929.

O'Brien, M. John Nolen and Raymond Unwin: Garden City Collaborators. Athens Journal of Architecture 1, no.1 (2015): 9-24.

Papadaki, E. and C. Bassima. Growth determinants of micro-businesses in Canada. Ottawa: Industry Canada, Small Business Policy Branch, 2002.

Peltz, J. It Started with Levittown in 1947: Nations $1^{\text {st }}$ Planned Community Transformed Suburbia. The Los Angeles Times, 1988. http://lat.ms/2vAy2QS. [Accessed 31 January, 2017].

Rodriguez, D. A., A. J. Khattak and K. R. Evenson. "Can new urbanism encourage physical activity?: Comparing a new Urbanist neighborhood with conventional suburbs." Journal of the American Planning Association 72, no.1 (2006): 43-54.

Rogers, M. F. John Nolen \& Mariemont: building a new town in Ohio. Millard F. Rogers, Jr. Baltimore: Johns Hopkins University Press, 2001, 126.

Rundle, Andrew et al. "Neighborhood food environment and walkability predict obesity in New York City." Environmental health perspectives 117, no.3 (2009): 442.

Scott, Mel. American city planning since 1890. Chicago, IL: American Planning Association, 1995, 72. 
Vol. 4, No. $1 \quad$ O'Brien: Remodeling the American Suburb, Obesity, Parklets...

Thorsson, S., T. Honjo, F. Lindberg, I. Eliasson and E. M. Lim. "Thermal comfort and outdoor activity in Japanese urban public places." Environment and Behavior, 2007.

Yeomans, Alfred P. City Residential Land Development, Studies in Planning, Competitive plans for subdividing a typical quarter section of land in the outskirts of Chicago. Chicago, Illinois: University of Chicago press, 1916. 